\title{
Studies on the zooplankton of the deep subalpine Lake Garda
}

\author{
Nico SALMASO* and Luigi NASELLI-FLORES ${ }^{1)}$ \\ Dipartimento di Biologia, Università di Padova, Via U. Bassi 58/B, I-35131 Padova \\ ${ }^{1)}$ Dipartimento di Scienze Botaniche, Università di Palermo, Via Archirafi 38, I-90123 Palermo \\ *e-mail corresponding author: salmaso@civ.bio.unipd.it
}

\begin{abstract}
The specific composition and seasonal dynamics of the zooplankton of Lake Garda have been studied through monthly surveys in two annual cycles (December 1994-November 1995 and January-December 1997). The assemblage is largely dominated by Copipodiaptomus steueri, a typical calanoid presently identified in deep (Garda, Iseo) and shallow lakes of NE Italy and in the hinterland of the central Adriatic region (Dalmatia and Marche Region). Cladocerans and the smaller rotifers represent a significant component of the zooplankton from spring to autumn. A re-examination of the results obtained in previous studies does not seem to demonstrate substantial shifts in the composition of the dominant species. The only documentable and consolidated differences are constituted by the disappearance of Sida crystallina since the '50s and the appearance of new rotifers since the '70s and the '80s. It is stressed that, owing to the fragmentation of the available studies and the use of different methodologies, the qualitative and quantitative modifications of the zooplankton should be interpreted with special caution, requiring further in-depth and continuous monitoring for the meaning they could have as possible signs of modifications of the trophic structure of the lake. However, the results of the comparison of the different investigations do not seem to contrast with the substantial stability of the oligo-mesotrophic character of the lake formally documented since the '70s.
\end{abstract}

Key words: zooplankton, seasonal dynamics, Lake Garda, deep lakes

\section{INTRODUCTION}

Zooplankton is an important constituent of the food chain in pelagic ecosystems. The zooplankton organisms feed on the phytoplankton, on bacteria, on aggregates of detritus and microorganisms as well as on other zooplankton species; furthermore, almost all freshwater fish feed on zooplankters at some stage in their life history (Moss 1988; Lampert \& Sommer 1997). Zooplankton may be of interest in the prediction of longterm changes in lake ecosystems. Despite some unavoidable taxonomic and methodological uncertainties, the comparison of measurements carried out in recent years with measurements made many years ago may give significant results in indicating signs of environmental changes (cf. Brock 1985).

The first observations on zooplankton organisms in Lake Garda (Fig. 1) began in the second half of the nineteenth century, in coincidence with the recognition of the existence of a planktonic fauna in lakes (Pavesi 1877). In agreement with the descriptive criteria at that time, the first studies were primarily directed towards the identification of zooplankton species and their distribution (e.g., Pavesi 1883; Garbini 1895; Brehm 1906; Brehm \& Zederbauer 1906). Comparisons of the microcrustaceans found until the '20s and '40s in Lake Garda and other deep southern subalpine lakes were made by Monti (1929) and Baldi (1949), respectively.

The first detailed studies on the zooplankton were carried out, on the basis of monthly samplings and on four stations (Fig. 1) representative of the whole lake, in the late $50 \mathrm{~s}$ in the framework of the most complete limnological research carried out until then in Lake Garda (Merlo 1959; Merlo \& Mozzi 1963).

From December 1970 to May 1972, studies were conducted with monthly samplings by IRSA (1974) in three representative stations located in the $\mathrm{W}$ and $\mathrm{E}$ basins of the lake (Fig. 1). Ten years later, Barbato (1988) carried out a series of seven seasonal samplings spanning from March 1982 to February 1983 in four stations located in the Gulf of Salò, in the SW zone of the lake; more recently, Negri \& Pelaia (1990) described the results obtained from monthly samplings in four stations in the W and E basins of the lake from September 1988 to September 1989 (Fig. 1).

Since 1991, limnological research was carried out in the $\mathrm{W}$ and $\mathrm{E}$ basins of Lake Garda by the Dipartimento di Biologia dell'Università di Padova (Salmaso et al. 1997b). Detailed information on phytoplankton assemblages, trophic evolution, chemical characteristics and thermal regime may be found in Salmaso (1996), Salmaso et al. (1997a), Salmaso \& Decet (1998). The principal objectives of this study are i) to evaluate the recent structure of the zooplankton in Lake Garda and ii) to compare the actual composition with that found in previous studies.

\section{METHODS}

Zooplankton was sampled monthly during two different annual cycles (December 1994-November 1995 
and January-December 1997) and in two pelagic stations located in the deepest zone of the $\mathrm{W}$ (Brenzone) and E (Bardolino) basins (Fig. 1). Samplings were carried out by single vertical tows from $20 \mathrm{~m}$ to the surface with a $25 \mathrm{~cm}$ diameter and $75 \mathrm{~cm}$ length net of $80 \mu \mathrm{m}$ mesh. The volume of water filtered has been determined indirectly assuming that the net filters the whole volume of the column of water traversed by the net (de Bernardi 1984). All samples were immediately fixed with $95 \%$ ethanol and examined in the laboratory with Zeiss invertoscopes. The most abundant organisms and rotifers were identified and counted on sedimentation chambers

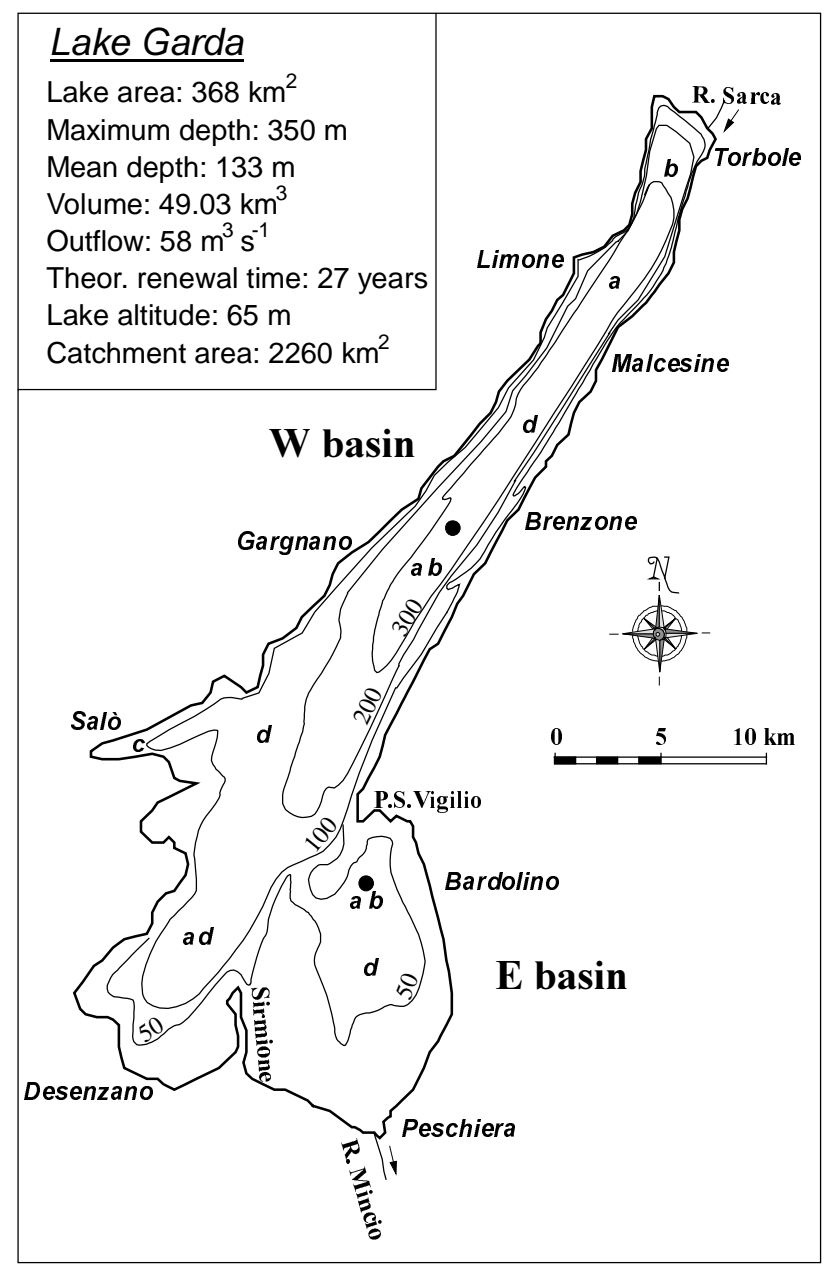

\section{RESULTS AND DISCUSSION}

\subsection{Species composition}

Zooplankton species identified in Lake Garda in the course of 1995 and 1997 include 30 taxa (Tab. 1). The assemblage was dominated, as number of species, by rotifers (21 taxa); Cladocera and Copepoda were found respectively with 3 and 6 taxa. The most representative member, found with high densities in all the samples, with magnification varying from 100 to $400 \times$ and subsample volumes chosen so that organisms did not pile up on one another (McCauley 1984). The less frequent or larger organisms (e.g., predatory Cladocera) were counted with a long working distance objective at $50 \times$ after sedimentation of larger subsamples $(10 \mathrm{ml})$ on Petri dishes. Identification of species was made according to Kiefer (1978), Stella (1984) and Einsle (1993) (Copepoda), Margaritora (1985) (Cladocera), RuttnerKolisko (1972) and Braioni \& Gelmini (1983) (Rotifera). The taxonomy of the family of Bosminidae was updated following Lieder (1996).

Fig. 1. Lake Garda: main morphometric and hydrological characteristics, bathymetric map (from IRSA 1974, modified) and location of the sampling stations (solid circles). The approximate location of the stations sampled in the previous works is indicated with: a (Merlo \& Mozzi 1963), b (IRSA 1974), c (Barbato 1988), d (Negri \& Pelaia 1990).

was the calanoid Copipodiaptomus steueri. Other frequent species, found in almost half of the samples in 1995 or 1997, were Mesocyclops leuckarti (Copepoda), Diaphanosoma brachyurum, Bosmina (Eubosmina) longicornis kessleri $(=B$. (Eub.) mixta kessleri) and Daphnia hyalina-galeata group (Cladocera), Ascomorpha ovalis, Asplanchna priodonta, Conochilus unicornis, Euchlanis dilatata, Kellicottia longispina, Keratella quadrata, Polyarthra spp. (including $P$. vulgaris and $P$. major), Synchaeta sp. and Trichocerca sp. (Rotifera). 
Tab. 1. List of zooplankton species found in Lake Garda during 1995 and 1997. Rarest taxa, identified only once, are indicated with "r". ${ }^{(a)}$ : including a single finding of $K$. cochlearis $\mathrm{f}$. tecta (Lauterborn) in 1997.

\section{COPEPODA}

Diaptomidae

Copipodiaptomus steueri (Brehm) Cyclopidae

Cyclops cf. abyssorum G.O. Sars

Mesocyclops leuckarti (Claus)

\section{CLADOCERA}

Sididae

Diaphanosoma brachyurum (Liévin) Bosminidae

Bosmina (Eub.) longicornis kessleri Uljanin Daphniidae

Daphnia hyalina-galeata group

Chydoridae

Chydorinae ind.

Cercopagidae

Bythotrephes longimanus Leydig

Leptodoridae

Leptodora kindtii (Focke)

\section{ROTIFERA}

Brachionidae

Brachionus quadridentatus Hermann

Keratella cochlearis (Gosse) ${ }^{(a)}$
Keratella quadrata (Müller)

Kellicottia longispina (Kellicott)

Euchlanis dilatata (Ehrenberg)

Lepadella ovalis (O.F. Müller)

Lecanidae

Lecane lunaris (Ehrenberg

Notommatidae

Cephalodella sp.

Trichocercidae

Trichocerca sp.

Trichocerca longiseta (Schrank)

Gastropodidae

Gastropus stylifer Imhof

Ascomorpha ovalis (Bergendahl)

Ascomorpha sp.

Synchaetidae

r Synchaeta sp.

Synchaeta lackowitziana Lucks

Polyarthra major Burckhardt

Polyarthra vulgaris Carlin

Ploesoma hudsoni (Imhof)

Asplanchnidae

Asplanchna priodonta Gosse

Testudinellidae

Filinia terminalis (Plate)

Conochilidae

Conochilus unicornis-hippocrepis group
Table 2 reports the list of the taxa recorded (at least at the genus level) in Lake Garda since the first complete study carried out in 1957-1958 with modern criteria (Merlo \& Mozzi 1963). Moreover, the list of Copepoda and Cladocera found in the lake until the 1940s (Baldi 1949) is reported. Current species names have been given to the taxa listed in the papers of previous authors (see Kiefer 1978, Margaritora 1985 and RuttnerKolisko 1972 for synonyms). The evaluation of the different lists allows to outline the species composition of the zooplankton in the last 40 years. However, owing to unavoidable methodological differences, the documentation of the disappearance and appearance of different species should be always considered with some caution when comparing the results of different investigations. This may be obvious in the case of sporadic findings but also when identification at the species level may be difficult or when a limited zone of the lake has been investigated (as in 1982-1983: Barbato 1988).

The three species of Copepoda appear to maintain an unaltered coexistence in all the studies considered. Some uncertainties are due to differences in the identification of Cyclops, reported as C. strenuus in Baldi (1949) and Merlo \& Mozzi (1963). On the other hand, as underlined by Einsle (1996), the "species" C. abysso- rum comprises a number of phenotypes and ecotypes that cannot be described or defined by morphological or morphometrical criteria only. Moreover, in the list of species compiled before the revision of the genus Eudiaptomus by Kiefer (1968), the dominant calanoid Copipodiaptomus steueri was reported as E. vulgaris. At present, the distribution of this species appears relatively restricted to an area comprised between NE Italy (Lake Garda and the lakes Iseo, Ledro, Cavazzo and S. Daniele del Friuli) and Dalmatia (Kiefer 1968; Stella 1984), with two findings in Central Italy (Marche: reservoirs of Fiastra and Caccamo, Kiefer 1978). Despite its absence in the list compiled by Merlo \& Mozzi (1963), the species M. leuckarti should be considered, in the same way as the other two copepods, a constant and typical constituent of the lake.

Among the cladocerans, the main difference is due to the disappearance of Sida crystallina beginning from the research of Merlo \& Mozzi (1963), at the end of the 50s. It is interesting to observe that, since the '60s and the '40s, this species was never found also in Lake Maggiore and Lake Lugano, respectively (De Bernardi \& Canale 1995, Polli \& Simona 1992). De Bernardi \& Canale (1995) correlated this disappearance with a significant development of an allochtonous coregonid 
(Coregonus macrophtalmus) introduced in Lake Maggiore in the middle of the '50s. Ravera \& Parise (1978) ascribed the disappearance of Sida to the progressive eutrophication of Lake Lugano. It is difficult to establish with any certainty the cause of the disappearance of this species from Lake Garda; however, a possible influence due to allochtonous fishes (e.g., Coregonus sp.: Oppi 1989) introduced in the lake since the beginning of this century should not be excluded.

Tab. 2. Comparison lists of zooplankton found in 1995/1997 and in previous years; only the taxa found at least at the genus level are reported. (i): Baldi (1949), (ii): Merlo \& Mozzi (1963), (iii): IRSA (1974), (iv): Barbato (1988), (v): Negri \& Pelaia (1990). The species which, on the whole, were found only sporadically are indicated by "r". ${ }^{(1)}$ : reported as Eudiaptomus vulgaris; ${ }^{(2)}$ : including C. abyssorum and C. strenuus; ${ }^{(3)}$ : including B. (Eub.) coregoni and B. (Eub.) l. kessleri; ${ }^{(4)}$ : reported as B. longicornis + B. coregoni; ${ }^{(5)}$ : including Daphnia hyalina $\times$ galeata.

\begin{tabular}{|c|c|c|c|c|c|c|c|c|}
\hline & & & $\begin{array}{l}1949 \\
\text { (i) }\end{array}$ & $\begin{array}{l}\text { 1957-1958 } \\
\text { (ii) }\end{array}$ & $\begin{array}{l}\text { 1970-1972 } \\
\text { (iii) }\end{array}$ & $\begin{array}{l}\text { 1982-1983 } \\
\text { (iv) }\end{array}$ & $\begin{array}{c}1987-1989 \\
\text { (v) }\end{array}$ & $\begin{array}{l}1995 / 1997 \\
\text { (this work) }\end{array}$ \\
\hline \multirow[t]{3}{*}{ COPEPODA } & \multicolumn{2}{|l|}{ Copipodiaptomus steueri } & $+^{(1)}$ & $t^{(1)}$ & + & + & + & + \\
\hline & \multicolumn{2}{|l|}{ Cyclops spp. ${ }^{(2)}$} & + & + & + & $(+)$ & + & + \\
\hline & \multicolumn{2}{|l|}{ Mesocyclops leuckarti } & + & & + & + & + & + \\
\hline \multirow[t]{9}{*}{ CLADOCERA } & \multicolumn{2}{|l|}{ Diaphanosoma brachyurum } & + & + & + & + & + & + \\
\hline & \multicolumn{2}{|l|}{ Sida crystallina } & + & & & & & \\
\hline & \multicolumn{2}{|l|}{ Bosmina (Eubosmina) spp. ${ }^{(3)}$} & $+(4)$ & + & + & + & + & + \\
\hline & \multicolumn{2}{|l|}{ Daphnia hyalina ${ }^{(5)}$} & & & + & + & + & + \\
\hline & \multicolumn{2}{|l|}{ Daphnia longispina } & + & + & & & & \\
\hline & \multicolumn{2}{|l|}{ Chydorus sp. } & & & & & + & \\
\hline & Polyphemus pediculus & $\mathrm{r}$ & & & & + & & \\
\hline & Bythotrephes longimanus & & + & + & + & & + & + \\
\hline & Leptodora kindtii & & + & + & + & + & + & + \\
\hline \multirow[t]{30}{*}{ ROTIFERA } & \multicolumn{2}{|c|}{ Brachionus quadridentatus $\mathrm{r}$} & & & & & & + \\
\hline & Brachionus sp. & $\mathrm{r}$ & & & + & & + & \\
\hline & Keratella cochlearis & & & $(+)$ & + & + & + & + \\
\hline & Keratella quadrata & & & & + & + & + & + \\
\hline & Kellicottia longispina & & & + & + & + & + & + \\
\hline & Euchlanis dilatata & & & & & & + & + \\
\hline & Lepadella ovalis & $\mathrm{r}$ & & & & & & + \\
\hline & Lecane luna & & & & + & & & \\
\hline & Lecane lunaris & & & & + & & + & + \\
\hline & Cephalodella sp. & & & & & & & + \\
\hline & Trichocerca longiseta & & & & & & & + \\
\hline & Trichocerca birostris & & & + & & & & \\
\hline & Trichocerca sp. & & & & + & + & + & + \\
\hline & Gastropus stylifer & & & + & + & + & + & + \\
\hline & Ascomorpha ovalis & & & + & + & & & + \\
\hline & Ascomorpha ecaudis & & & & & + & + & \\
\hline & Ascomorpha sp. & & & & & & & + \\
\hline & Synchaeta lackowitziana & & & & + & & & + \\
\hline & Synchaeta pectinata & & & + & + & + & & \\
\hline & Synchaeta sp. & & & + & + & + & + & + \\
\hline & Polyarthra major & & & & & & & + \\
\hline & Polyarthra vulgaris & & & + & + & + & + & + \\
\hline & Ploesoma hudsoni & $\mathrm{r}$ & & & & & & + \\
\hline & Ploesoma sp. & & & + & + & & & \\
\hline & Asplanchna priodonta & & & + & + & + & + & + \\
\hline & Filinia longiseta & & & & & & + & \\
\hline & Filinia terminalis & & & + & + & & + & + \\
\hline & Filinia sp. & & & & & + & & \\
\hline & Hexarthra mira & & & + & & & & \\
\hline & Conochilus unicornis-hippc & repis & & + & + & + & + & + \\
\hline
\end{tabular}

A further problem is constituted by the taxonomy of Daphnia, reported as D. longispina until the work of Merlo \& Mozzi (1963) and afterwards as D. hyalina (Tab. 2). As underlined by Margaritora (1985), both these species are characterised by a great number of types which make their nomenclature rather difficult; moreover, in various deep Italian lakes $D$. hyalina has been reported under the generic name of $D$. longispina. In our investigations, the identification of $D$. hyalina has been complicated by the appearance, principally during the warmest months, of morphotypes with characteristics, following Flössner \& Kraus (1986), resembling 
those of D. galeata. However, in most cases the microscopic examination does not always appear satisfactory enough for a definitive differentiation of these specimens (see also Glagolev 1986). This taxonomical problem may be complicated by the widespread occurrence of hybrids between D. hyalina and D. galeata (Flössner 1993). Taking into account these problems, and owing to some uncertainties in differentiating clearly the seasonal succession of different morphotypes, at present they have been conditionally included in the D. hyalinagaleata group. It is interesting to observe that in Lake Maggiore the appearance of two new forms of Daphnia (D. galeata and D. cucullata), besides D. hyalina, which was reported as the only species of this group in the lake since the beginning of this century, was documented beginning from 1988 (de Bernardi \& Canale 1995).

The taxonomy of the genus Bosmina represents another interesting problem. In all the preceding investigations (Tab. 2) the reported species was Bosmina (Eubosmina) coregoni (with the addition of B. (Eub.) longicornis in Baldi (1949)). However, the presence of a clearly distinguishable mucrone contrasted with the features of the coregoni-type; a closer investigation of the specimens of this genus allowed their identification as B. (Eub.) longicornis kessleri Uljanin $(=B$. (Eub.) mixta kessleri (Uljanin)), F.G. Margaritora det.). The differences in these determinations may be only apparent. In fact, the relative position of $B$. (Eub.) longicornis within the subgenus has been the subject of much debate, with some authors considering it as a subspecies of B. (Eub.) coregoni (for a brief history of this taxon see Lieder \& Günther (1995)). Moreover, the presence of the "mucronate" form - reported both as B. longicornis (Garbini 1895; Pavesi 1883) or as a subspecies of $B$. (Eub.) coregoni (subsp. longicornis: Margaritora 1985) - was well known in Lake Garda since the first collection of zoological samples. However, it should be stressed that the classification of this taxon, being related to hybridisation processes (Lieder 1991), is still difficult ("kessleri ist die Crux der Eubosmina-Taxonomie" Lieder 1996).

Other differences in the group of cladocerans appear of secondary importance, as the occasional finding of Chydorus sp. and Polyphemus pediculus in the '80s.

The changes observed in the composition of rotifers must be interpreted with some caution. The composition of this heterogeneous and large group may be greatly influenced by the sampling strategy (Ruttner-Kolisko 1977) as well as by the occurrence of a greater number of the rarest forms in comparison to the copepods and cladocerans. In fact, the organisms found only in a single sampling campaign are represented by 12 taxa (Tab. 2 ). Conversely, the rotifers found by all the authors are Keratella cochlearis, Kellicottia longispina, Gastropus stylifer, Synchaeta sp., Polyarthra vulgaris, Asplanchna priodonta and Conochilus spp. On the whole, in Lake Garda this last genus appears to include at least two species (C. unicornis, the only one reported before this work, and C. hippocrepis). The identification of $C$. hippocrepis in our samples has been easily carried out only with living specimens, because the character of the antennae was not always well represented in the fixed samples. For this reason, and following the suggestions of Manca \& Sonvico (1996), we have adopted the term Conochilus unicornis-hippocrepis group to identify this organism in Lake Garda.

The evaluation of the long-term changes of some species of rotifers may be rather complicated when identifications include also generic names, as in the case of Brachionus, Trichocerca, Ascomorpha, Synchaeta and Filinia. However, apart from Brachionus, sporadically identified only after the '70s, these genera were found in all the considered periods; apparently, Filinia terminalis has also been a typical pelagic constituent of the lake, since it was not found only in the work of Barbato (1988) which reports the presence of Filinia sp. Probably, the most interesting and consolidated modifications within this group are the appearance of the new species Keratella quadrata and Lecane lunaris since the '70s, and Euchlanis dilatata since the second half of the '80s.

\subsection{Seasonal variations of the dominant species}

Figures 2, 3 and 4 report the seasonal variations of selected groups or species of copepods, cladocerans and rotifers in 1995 and 1997. In figure 2 copepods are subdivided between calanoids, cyclopoids and total nauplii, whereas figure 3 reports all the species of cladocerans found, with the exclusion of an isolated finding of an undetermined Chydoridae on September 1997 at Bardolino. Owing to the great development of Conochilus in 1997, in figure 4 the densities of this organism are reported separately from those of other rotifers.

The temporal evolution of cladocerans and, to a lesser extent, copepods, is characterised by the presence of a discrete seasonal component, with higher densities during the spring-summer months and/or autumn months (Figs 2 and 3). Rotifers have their greatest development in spring and, partly, during autumn in 1995 and early spring and summer in 1997 (Fig. 4). However, apart differences in the timing of maximum development, the cyclical character in the evolution of the zooplankton assemblage has different amplitude in the two study years. In particular, in 1995 the cladocerans showed a more pronounced development, whereas, in 1997, rotifers were dominated by a strong number of Conochilus.

In general, the whole assemblage and the three distinct zooplankton groups have a comparable temporal evolution in the western and eastern sub-basins of the lake (Tab. 3).

The seasonal evolution of copepods is almost entirely determined by C. steueri (Fig. 2). In 1995 this species reaches its higher densities $(25,000-55,000$ ind 
$\mathrm{m}^{-3}$ ) in summer and (at Brenzone) autumn months. In 1997 it is possible to distinguish two periods of high development in spring (mainly at Bardolino) and during summer (up to 40,000 ind $\mathrm{m}^{-3}$ in both stations). The dominance of this species among the copepods confirms the results of previous works (afterwards the densities cited or recomputed from other papers include adults+ copepodites). Merlo \& Mozzi (1963) found a maximum density, in the layer $0-25 \mathrm{~m}$, of ca 13,500 ind $\mathrm{m}^{-3}$ in
September. In the investigations of IRSA (1974) higher densities (between 45,000-77,000 ind $\mathrm{m}^{-3}$ ) in the first 25 $\mathrm{m}$ were found in spring and autumn. Barbato (1988) reported a maximum density of 26,000 ind $\mathrm{m}^{-3}$, with the higher values reached from spring to autumn. Negri \& Pelaia (1990) found a general increase during spring and summer (with maximum values always below 17,000 ind $\mathrm{m}^{-3}$ ) and minimum values in October.
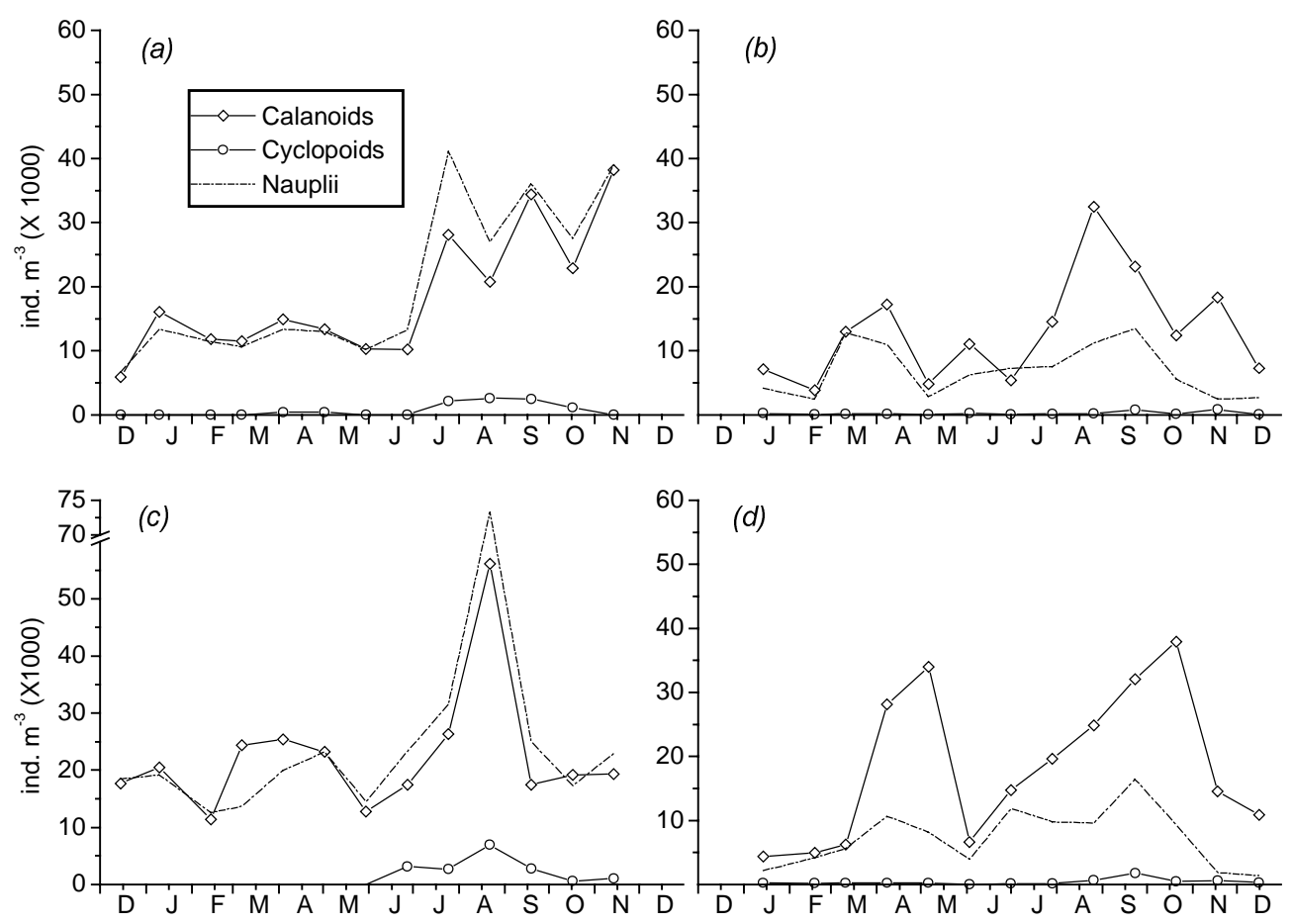

Fig. 2. Density variations of calanoids (Copipodiaptomus), cyclopoids (Mesocyclops, Cyclops) and nauplii at Brenzone (a, b) and Bardolino $(c, d)$ in 1995 (left panels) and 1997 (right panels). "Calanoids" and "cyclopoids" include adults + copepodites.

The difficulty to find some regularity in the seasonal development of $C$. steueri may be due to its policyclic character, well evidenced by the presence of ovigerous females in all the samples.

In comparison to $C$. steueri, the cyclopoids are present with a low number of individuals. The most frequent and abundant between the two species living in Lake Garda is M. leuckarti. In both years, the maximum development is attained in a limited period, between the summer and autumn months, i.e. July-September in 1995 (up to 6500 ind $\mathrm{m}^{-3}$ ) and August-November in 1997 (up to 1800 ind $\mathrm{m}^{-3}$ ), thus confirming the warmstenothermal character of this species (IRSA 1974; Negri \& Pelaia 1990). On the contrary, Cyclops cf. abyssorum has been identified in a limited number of samples ( $c$ a $20 \%$ of the total) and with densities generally below 500 ind $\mathrm{m}^{-3}$ (with the exception of two isolated peaks of 2000 and 1000 ind $\mathrm{m}^{-3}$ in June and November 1995). The development of this species appears mainly limited to the cold and mild months (autumn- spring), a feature observed also in the previous research (IRSA 1974; Negri \& Pelaia 1990). A similar seasonality was observed in Lake Maggiore by Ravera (1954), so that this species was defined cold-stenothermal.

The numerical prevalence of Mesocyclops over Cyclops is confirmed also by the investigations made in the 80s. Barbato (1988) found Mesocyclops with a maximum density of $c a 3200$ ind $\mathrm{m}^{-3}$, but was able to identify some specimens of Cyclops only after further appropriate samplings, successively not included in his research. In the investigations of Negri \& Pelaia (1990) the highest densities of Mesocyclops and Cyclops in the whole lake were between 200-1100 and 50-300 ind $\mathrm{m}^{-3}$, respectively. It is interesting to observe that, in the beginning of the 70s (IRSA 1974) the relative importance of these two cyclopoids appeared inverted in favour of Cyclops; between 0-25 m, this species was found with maximum densities up to 5000 ind $\mathrm{m}^{-3}$ (April), whereas Mesocyclops reached a density around 1300 ind $\mathrm{m}^{-3}$ (May). 

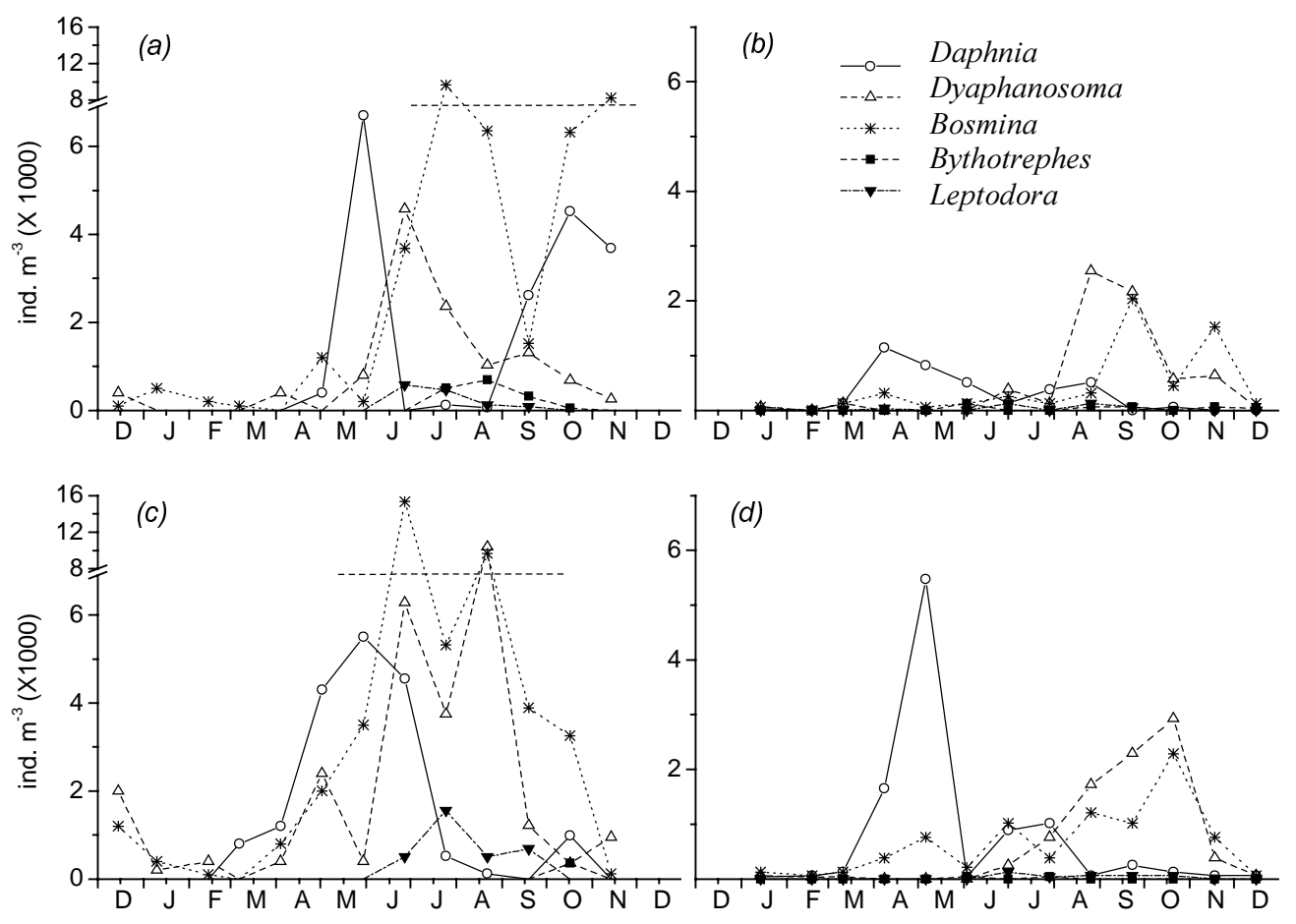

Fig. 3. Density variations of cladocerans at Brenzone $(a, b)$ and Bardolino $(c, d)$ in 1995 (left panels) and 1997 (right panels).

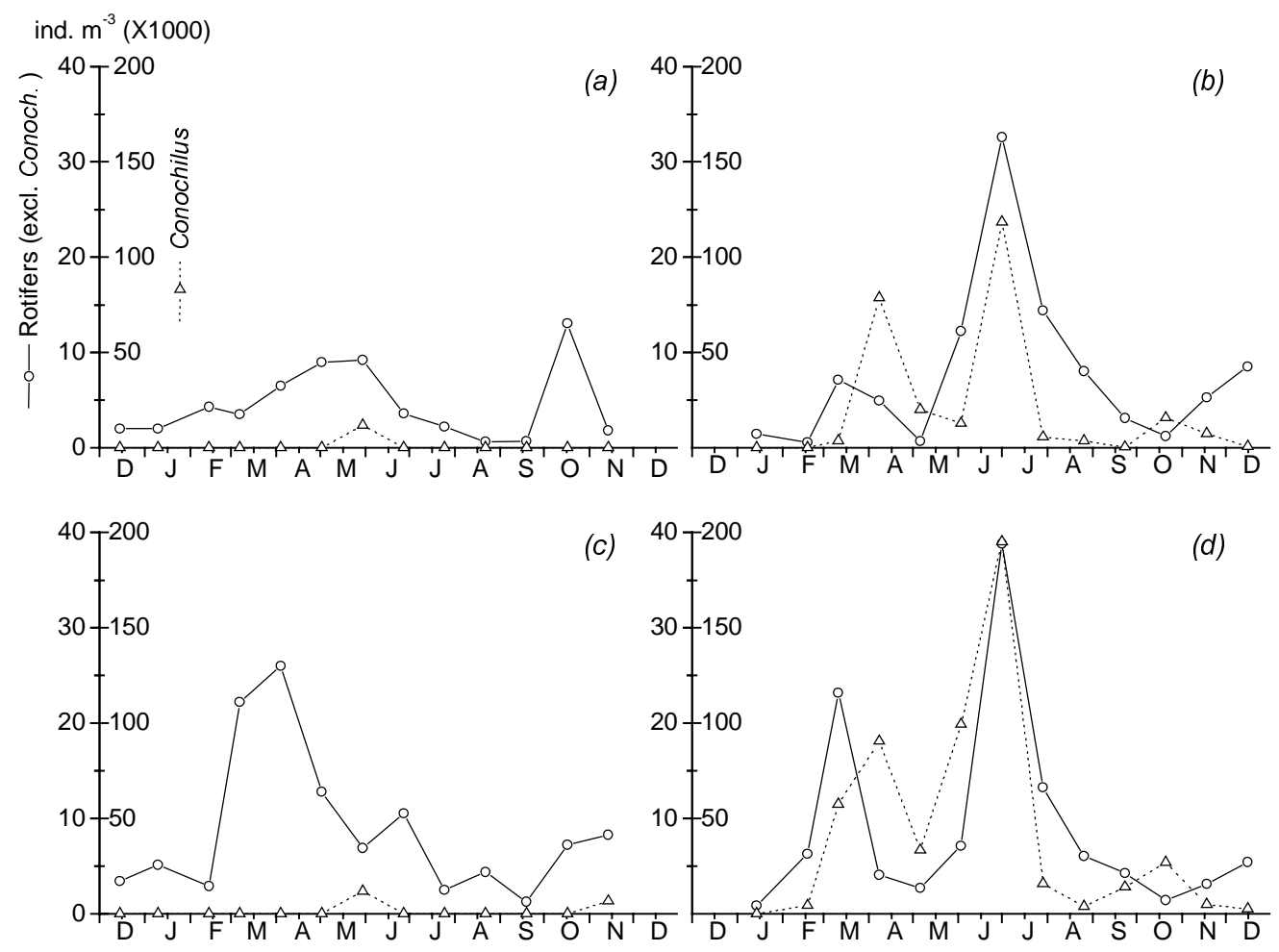

Fig. 4. Density variations of Conochilus and the remaining rotifers (excluding Conochilus) at Brenzone ( $a, b)$ and Bardolino (c, $d$ ) in 1995 (left panels) and 1997 (right panels). 
Tab. 3. Correlation coefficients among the zooplankton densities quantified at Brenzone and Bardolino in the two study years $(n=26)$; the figure in italic is significant at $P<0.05$, the others at $P<0.01$.

\begin{tabular}{lcccc}
\hline & Total density & Copepoda & Cladocera & Rotifera \\
\hline Untransformed data & 0.74 & 0.61 & 0.47 & 0.91 \\
Log transformed & 0.70 & 0.62 & 0.69 & 0.78 \\
\hline
\end{tabular}

The three most frequent cladocerans (Daphnia spp., $D$. brachyurum and B. (Eub.) l. kessleri) have their higher densities only from spring to early autumn (Fig. 3 ). The timing of the maximum development and seasonal replacement of these species is comparable in the two study years and in both stations. Daphnia is characterised by a well defined spring pulse delimited in a restricted period between April and June. In the other months densities are generally lower, even if it is possible to observe a successive tendency towards an increase in summer (1997) or autumn (1995). The tendency towards the development of a subsequent maximum following the spring peaks was observed also in Lake Maggiore, but only at irregular intervals (de Bernardi \& Canale 1995). D. brachyurum and B. (Eub.) $l$. kessleri have their maximum development in summer and autumn. However, the density of Bosmina appears to increase earlier, during the spring development of Daphnia, whereas, excluding a relative high value recorded during spring 1995 at Bardolino, Diaphanosoma shows its distinctive maximum during the warmest months.

The analysis of the data reported in previous works permits to delineate a more or less similar seasonal replacement among the three phytophagous cladocerans, particularly in the investigations carried out in the pelagic environment (Merlo \& Mozzi 1963; IRSA 1974; Negri \& Pelaia 1990). In the layer 0-25 m Merlo \& Mozzi (1963) reported the maximum growth of Daphnia during spring (1700 ind $\mathrm{m}^{-3}$ ), whereas Bosmina (up to 700 ind $\mathrm{m}^{-3}$ ) and Diaphanosoma (over 2700 ind $\mathrm{m}^{-3}$ ) were mainly present in summer and autumn. Data reports included in IRSA (1974) permit to observe, in the first $25 \mathrm{~m}$, a spring pulse of Daphnia beginning in April (5000-1300 ind $\mathrm{m}^{-3}$ ) followed by maximum values of Bosmina in May (4000-7500 ind $\mathrm{m}^{-3}$ ) and an increase of Diaphanosoma during summer and early autumn (up to 8000 ind $\mathrm{m}^{-3}$ ). The results reported by Negri \& Pelaia (1990) show a clear correspondence in the spring development of both Daphnia and Bosmina (with densities up to 7000 and 2000 ind $\mathrm{m}^{-3}$, respectively) with a successive maximum of Diaphanosoma (up to 6000 ind $\mathrm{m}^{-3}$ ).

The alternating development between Daphnia and Diaphanosoma may be due, as evidenced by de Bernardi \& Canali (1975) and Horn \& Horn (1990), to competitive mechanisms, the same which may explain the relationships between the population dynamics of Daphnia and Eubosmina (de Bernardi \& Canale 1995).
On the other hand, as evidenced by the same authors, the mutual interactions among these three species may be significantly influenced by their selective predation; it was shown that, depending on the size, D. hyalina is the preferred food for planktivorous fishes or for Bythotrephes and Leptodora, whereas Eubosmina and Diaphanosoma do not contribute to the diet of planktivorous fishes, but are caught by the invertebrate predators (see references in de Bernardi \& Canale 1995). L. kindtii (a warm-stenothermal species) was found in samples between April and September (with

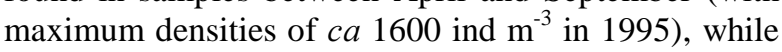
B. longimanus between June and December (up to 700 ind $\mathrm{m}^{-3}$ in 1995).

The explanation of the factors responsible of the wax and wane of cladocerans will require, besides interspecific competition and fish predation, an indepth analysis of food requirement.

When considering the seasonal evolution of both copepods and cladocerans, their daily vertical migration behaviour must be taken into consideration (Lampert \& Sommer 1997), especially in large lakes when only a limited strata has been sampled in relation to the maximum depth. In this context, and considering its low densities, this may be of particular importance for Cyclops. In fact, as observed by Einsle (1996), the populations of $C$. abyssorum which live in the subalpine, large and deep lakes ("prealpinus"-group) prefer the deeper water layers (40-60 m of depth) during daytime, migrating to the surface only during the night. On the contrary, as shown by the work of IRSA (1974), $M$. leuckarti appears confined, in the daytime, in the strata between 0-25 m. The same may be important also for cladocerans (see Stich \& Lampert 1981 for examples on migrations of Daphnia in the deep Lake Constance).

Among the Rotifera, the most abundant species are represented, in 1995 and/or 1997, by A. ovalis, E. dilatata, K. longispina, Polyarthra spp. (with maximum densities ranging from 7000 to 13,500 ind $\mathrm{m}^{-3}$ ) and by Conochilus, which, in 1997, attained density peaks of ca 110,000 and 190,000 ind $\mathrm{m}^{-3}$ at Brenzone and Bardolino, respectively (Fig. 4). Other important species, reaching densities around 5000 ind $\mathrm{m}^{-3}$, are represented by G. stylifer, K. cochlearis and Synchaeta sp.

The seasonal development of Rotifera is characterised by a spring pulse and a successive maximum development reached during autumn in 1995 and summer in 1997; however, the most noticeable difference between the two study years is represented by the major 
development of Conochilus in 1997. Excluding this species (discussed below) the maximum densities attained by the remaining rotifers in the previous investigations carried out in pelagic stations (Merlo \& Mozzi 1963; IRSA 1974; Negri \& Pelaia 1990) are comprised in the range of maximum values found at Brenzone and Bardolino in the two study years (Fig. 4). However, the relative development of the different species was not always directly comparable with that found in 1995/97. For example, the investigations carried out by IRSA (1974) identified a significant development of $\mathrm{A}$. priodonta and Synchaeta sp. (up to 27,000 and 21,000 ind $\mathrm{m}^{-3}$ in the first $25 \mathrm{~m}$ ). As regards Conochilus, density peaks were recorded also in previous research, but with values comparable to those observed in 1997 only in the investigations of IRSA (1974) where in the layer 0$25 \mathrm{~m}$ two periods of higher development were identified, one in the whole lake, in spring (up to 115,000 ind $\mathrm{m}^{-3}$ in the $\mathrm{W}$-basin) and the other in the southern basin, in autumn (45,000 ind $\left.\mathrm{m}^{-3}\right)$. Merlo \& Mozzi (1963) found two maxima (up to 4500 ind $\mathrm{m}^{-3}$ between $0-25$ m) in summer and autumn. Negri \& Pelaia (1989) found a single spring pulse in the whole lake, with maximum densities ranging from 11,000 to 25,000 ind $\mathrm{m}^{-3}$.

The irregular character found in the development of Conochilus in Lake Garda, as regards both the seasonality and the maximum densities attained in the different years, has been verified also in other lakes. In particular, in Lake Washington C. unicornis appeared sporadically and usually in small numbers during a total of 28 years of observations since 1933; C. hippocrepis has been even more sporadic and less conspicuous until a 3 -year period at the end of the 70s when it became extraordinarily abundant, with a peak of $10^{6}$ ind $\mathrm{m}^{-3}$ (Edmondson \& Litt 1987). In this lake the only consistent correlation found was between the seasonal maximum of Leptodora and the decrease of Conochilus from its peak abundance each year. More recently, Manca \& Sonvico (1996) observed that, in Lake Maggiore, the colonies of Conochilus became numerically important in comparison to previous research; besides Leptodora, the predation pressure of Bythotrephes was considered to contribute significantly to the summer depletion of Conochilus which, at least during JuneJuly, represented a large proportion of the total preferred prey of the two predatory Cladocera.

In Lake Garda, the maximum development of Conochilus in 1997, paralleled by a lower development of Leptodora and Bythotrephes in comparison to 1995 (Fig. 3), would find some interpretations in the light of the above observations. In particular, the development of Conochilus at the end of May in 1995 stopped abruptly in June, in coincidence with the rapid growth of Leptodora (Figs 3a, c). In 1997 the mutual relationships among predators and prey appear less defined, with the greatest development of Conochilus occurring in the whole range of density of the two invertebrate predators (0-150 ind $\left.\mathrm{m}^{-3}\right)$. However, the discrimination of the whole set of factors responsible of the growth and decline of the Conochilus colonies requires, as underlined by Edmondson \& Litt (1987) and Manca \& Sonvico (1996), further studies clarifying better the role of food availability (Conochilus accepts particles of 10 to $12 \mu \mathrm{m}$, Pourriot 1977) and the abilities of Leptodora and other plankton predators to find, catch and consume Conochilus.

\section{CONCLUSIONS}

The studies carried out in 1995 and 1997 in Lake Garda have revealed an assemblage largely dominated by $C$. steueri, a typical species identified also in other deep (Iseo) and shallow lakes of NE Italy and of the hinterland of the central Adriatic Region (Dalmatia and Marche Region). Cladocerans (D. hyalina-galeata group, B. (Eub.) l. kessleri, D. brachyurum and invertebrate predators), together with rotifers, represent a significant component of the zooplankton from spring to autumn.

The zooplankton of Lake Garda presents traits typical of deep lakes with moderate productivity, where the calanoids constitute the main component in comparison with cladocerans and smaller rotifers. Such composition was evidenced since the first studies carried out from the beginning of this century. Excluding unavoidable modifications due to the improvement of taxonomy and species description in the last decades, the documentable and consolidated differences in the list of species appear mainly due to the disappearance of $S$. crystallina since the '50s and the appearance of new rotifers since the '70s ( $K$. quadrata, L. lunaris) and the '80s (E. dilatata). The quantitative comparison of our data with those of the previous works carried out in pelagic stations (Merlo \& Mozzi 1963; IRSA 1974; Negri \& Pelaia 1990) are difficult to interpret, also in the light of significant differences in the maximum densities reached by different groups and species in the two recent study years, 1995 and 1997. On the other hand, owing to the fragmentation of the available studies and the use of different methodologies, the qualitative and quantitative modifications observed in the seasonal development of the zooplankton community in Lake Garda should be interpreted with special caution, particularly as regards the rotifers. From this point of view the irregular development of Conochilus or the appearance of new rotifers are difficult to decipher and should require further in-depth and continuous observations for their interpretation as possible signs of modifications in the trophic structure of the lake.

All in all, but with the limitations deriving from the above considerations, the results of the comparison of the different investigations presented here do not seem to contrast with the substantial stability in the oligo- 
mesotrophic character of the lake formally documented, although on the basis of non-continuous studies, since the 70s (e.g., IRSA 1974; Salmaso et al. 1997a, b). On the other hand, most observations show that changes in the composition of the species inhabiting a lake may occur only after considerable changes in its trophic level. For example, during the 70s, when Lake Maggiore reached its maximum eutrophication, a reduction in the relative importance of copepods in favour of cladocerans and rotifers was observed together with an increase in the total population density of the zooplankton and a significant development of new species (Chydorus sphaericus) (Manca et al. 1992).

The only way to evaluate adequately the efficiency of political interventions aimed at the control of nutrients and the maintenance of good water quality in lakes is constituted, besides experimental determinations of chemical loads and in-lake concentrations, by long term-studies of the biological components, principally those at the base of the trophic chains. Owing to the present low concentrations of phosphorus compounds in the euphotic layers (with annual average concentrations around $10 \mu \mathrm{g} \mathrm{TP}{ }^{-1}$ ), the trophic status of Lake Garda does not seem to show any apparent trend towards eutrophication; in the period 1992-1997 mean annual values of epilimnetic chlorophyll- $a$ in the $\mathrm{W}$ and $\mathrm{E}$ basins were, with the exclusion of a low value

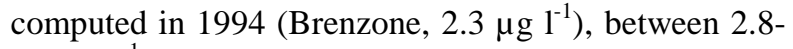
$4.0 \mathrm{\mu g} \mathrm{l}^{-1}$ (Salmaso et al. 1997b and unpublished data). However, the increase of total and reactive- $P$ in the hypolimnion of Lake Garda since the '80s (Mosello et al. 1997) demonstrates an increase in its trophic potentiality giving, at the same time, indications about the uncertainty of defining precisely future scenarios in the productive layers (Salmaso et al. 1997a). In this light, continuous studies of the plankton communities should become an inalienable feature in the management of Lake Garda, due to the ability of both zooplankton and phytoplankton assemblages to rearrange their relative composition and growth in reply to changing conditions.

\section{ACKNOWLEDGMENTS}

We wish to express our gratitude to Prof. Fiorenza G. Margaritora of the Dipartimento di Biologia dell'Università di Roma "La Sapienza" for her help in resolving the taxonomy of the Bosmina genus. Special thanks are due to Prof. Maria G. Braioni of the Dipartimento di Biologia dell'Università di Padova and to Dr. Marina Manca of the CNR Istituto italiano di Idrobiologia, Pallanza, for their suggestions and help in identifying rotifers and intractable hybrids of Daphnia, respectively. We are grateful to Prof. Paolo Cordella (Dipartimento di Biologia, Padova) and to the staff of the ARPAV-Verona, for critical discussions and logistic support. Thanks are also due to Dr. Elisabetta Oddo for the revision of the English text and to an anony- mous referee for remarks and suggestions. This work was partially funded by the Veneto Region.

\section{REFERENCES}

Baldi, E. 1949. Alcuni caratteri generali dei laghi marginali sudalpini. Verh. int. Ver. Limnol., 10: 50-69.

Barbato, G. 1988. Indagine sul popolamento zooplanctonico del Golfo di Salò (Lago di Garda, Brescia). Natura Bresciana, 25: 173-186.

Braioni, M.G. \& D. Gelmini. 1983. Rotiferi Monogodonti (Rotatoria: Monogodonta). Guide per il riconoscimento delle specie animali delle acque interne italiane, 23. CNR AQ/1/200: $180 \mathrm{pp}$.

Brehm, V. 1906. Zur Planktofauna des Gardasees. Arch. Hydrobiol., 1: 496-497.

Brehm, V. \& E. Zederbauer. 1906. Beobachtungen über das Plankton in den Seen der Ostalpen. Arch. Hydrobiol., 1: 469-495.

Brock, T.D. 1985. A eutrophic lake. Lake Mendota, Wisconsin. Ecol. Stud. 55: 308 pp.

de Bernardi, R. 1984. Methods for the estimation of zooplankton abundance. In: J.A. Downing \& F.H. Rigler (Eds), A manual on methods for the assessment of secondary productivity in fresh waters. IBP Hanbook 17. Blackwell Scientific Publications: 59-86.

de Bernardi, R. e C. Canale. 1995. Ricerche pluriennali (1948-1992) sull'ecologia dello zooplancton del Lago Maggiore. Documenta Ist. ital. Idrobiol. 55: 68 pp.

de Bernardi, R. \& E. Canali. 1975. Population dynamics of pelagic cladocerans in Lago Maggiore. Mem. Ist. ital. Idrobiol., 32: 365-392.

Edmondson, W.T. \& A.H. Litt. 1987. Conochilus in Lake Washington. Hydrobiologia, 147: 157-162.

Einsle, U. 1993. Crustacea, Copepoda: Calanoida und Cyclopoida. Süßwasserfauna von Mitteleuropa. Band 8/4-1. Gustav Fisher Verlag, Stuttgart: 209 pp.

Einsle, U. 1996. Copepoda: Cyclopoida. Genera Cyclops, Megacyclops, Acanthocyclops. Guides to the Identification of the Microinvertebrates of the Continental Waters of the World, 10: $83 \mathrm{pp}$.

Flössner, D. 1993. Zur Kenntnis einiger Daphnia-Hybriden (Crustacea: Cladocera). Limnologica, 23: 71-79.

Flössner, D. \& K. Kraus. 1986. On the taxonomy of Daphnia hyalina-galeata complex (Crustacea: Cladocera). Hydrobiologia, 137: 97-115.

Garbini, A. 1895. Fauna limnetica e profonda del Benaco. Boll. Zool. Anat. comp., Torino, 198 (X): 7 pp.

Glagolev, S.M. 1986. Species composition of Daphnia in Lake Glubokoe with notes on the taxonomy and geographical distribution of some species. Hydrobiologia, 141: 55-82.

Horn, W. \& H. Horn. 1990. Long-term relationships between phyto- and zooplankton in the meso-eutrophic Reservoir Saidenbach. Arch. Hydrobiol. Beih. Ergebn. Limnol., 33: 749-762.

IRSA. 1974. Indagini sul Lago di Garda. (Ed.: M. Gerletti). IRSA Quaderni 18, Roma: 540 pp.

Kiefer, F. 1968. Versuch einer revision der gattung Eudiaptomus Kiefer (Copepoda, Calanoida). Mem. Ist. ital. Idrobiol., 24: 9-160.

Kiefer, F. 1978. Freilebende Copepoda. Das Zooplankton der Binnengewässer. Band XXVI, 2. Teil. E. Schweizerbart'sche Verlagsbuchhandlung, Stuttgart: 343 pp.

Lampert, W. \& U. Sommer. 1997. Limnoecology. The ecology of lakes and streams. Oxford University Press: $382 \mathrm{pp}$.

Lieder, U. 1991. The Bosmina kessleri-like morphotype of Eubosmina in Lake Muskoka, Ontario, Canada, as putative interspecific hybrids. Hydrobiologia, 225: 71-80. 
Lieder, U. 1996. Crustacea : Cladocera, Bosminidae. Süßwasserfauna von Mitteleuropa. Band 8/2-3. Gustav Fisher Verlag, Stuttgart: $80 \mathrm{pp}$.

Lieder, U. \& J. Günther. 1995. Bosmina (Eubosmina) longicornis longicornis Schoedler, 1866 (Crustacea, Cladocera: Bosminidae) from the postglacial sediments of the Neuendorfer See, East Germany. Int. Revue ges. Hydrobiol., 80: 111-120.

Manca, M. \& D. Sonvico. 1996. Seasonal variations in population density and size structure of Conochilus in Lago Maggiore: a biannual study. Mem. Ist. ital. Idrobiol., 54: 97-108.

Manca, M., A. Calderoni \& R. Mosello. 1992. Limnological research in Lago Maggiore: studies on hydrochemistry and plankton. Mem. Ist. ital. Idrobiol., 50: 171-200.

Margaritora, F.G., 1985. Cladocera. Ed. Calderini, Bologna: 399 pp.

McCauley, E. 1984. The estimation of the abundance and biomass of zooplankton in samples. In: J.A. Downing \& F.H. Rigler (Eds), A manual on methods for the assessment of secondary productivity in fresh waters. IBP Handbook 17. Blackwell Scientific Publications: 228265.

Merlo, S. 1959. Distribuzione e frequenza del plancton del Lago di Garda. Boll. Zool., 26: 383-396.

Merlo, S. \& C. Mozzi. 1963. Ricerche limnologiche sul Lago di Garda. Arch. Oceanogr. Limnol., 13: 1-125.

Monti, R. 1929. Limnologia comparata dei laghi insubrici. Verh. int. Ver. Limnol., 4: 462-497.

Mosello, R., A. Calderoni \& R. de Bernardi. 1997. Le indagini sulla evoluzione dei laghi profondi sudalpini svolte dal C.N.R. Istituto italiano di Idrobiologia. Documenta Ist. ital. Idrobiol., 61: 19-32.

Moss, B. 1988. Ecology of freshwaters. Man and medium. Blakwell Science Ltd, 2nd ed.: 417 pp.

Negri, A. \& S. Pelaia. 1990. Analisi dei risultati: lo zooplancton. In: G. Chiaudani \& G. Premazzi (Eds), Il Lago di Garda. Evoluzione trofica e condizioni ambientali attuali. Commissione delle Comunità Europee, EUR 12925, Lussemburgo: 137-141.

Oppi, E. 1989. Ricerche sui pesci del Lago di Garda. Cooperativa fra Pescatori Garda, Centro Studi per il Territorio Benacense, Amministrazione Provinciale di Verona: 303 pp.

Pavesi, P. 1877. Intorno alla esistenza della "fauna pelagica" e d'alto lago anche in Italia. Boll. Soc. Entomol. Ital., Firenze, 9(8): 4 pp.

Received: February 1999

Accepted: April 1999
Pavesi, P. 1883. Altra serie di ricerche e studi sulla fauna pelagica dei laghi italiani. Atti Soc. Veneto-Trentina Sc. Nat., Padova, 8(2): 340-403.

Polli, B. \& M. Simona. 1992. Qualitative and quantitative aspects of the evolution of the planktonic populations in Lake Lugano. Aquat. Sci., 54: 303-320.

Pourriot, R. 1977. Food and feeding habits of Rotifera. Arch. Hydrobiol. Beih. Ergebn. Limnol., 8: 243-260.

Ravera, O. 1954. La struttura demografica dei copepodi del Lago Maggiore. Mem. Ist. ital. Idrobiol., 8: 109-150.

Ravera, O. \& G. Parise. 1978. Eutrophication of Lake Lugano "read" by means of planktonic remains in the sediment. Schweiz. Z. Hydrol., 40: 40-50.

Ruttner-Kolisko, A. 1972. Rotatoria. Das Zooplankton der Binnengewässer. Band XXVI, 1. Teil. E. Schweizerbart'sche Verlagsbuchhandlung, Stuttgart: 99-234.

Ruttner-Kolisko, A. 1977. Comparison of various sampling techniques, and results of repeated sampling of planktonic rotifers. Arch. Hydrobiol. Beih. Ergebn. Limnol., 8: 13-18.

Salmaso, N. 1996. Seasonal variation in the composition and rate of change of the phytoplankton community in a deep subalpine lake (Lake Garda, Northern Italy). An application of nonmetric multidimensional scaling and cluster analysis. Hydrobiologia, 337: 49-68.

Salmaso, N. \& F. Decet. 1998. Interactions of physical, chemical and biological processes affecting the seasonality of mineral composition and nutrient cycling in the water column of a deep subalpine lake (Lake Garda, Northern Italy). Arch. Hydrobiol., 142: 385-414.

Salmaso, N., F. Decet \& R. Mosello. 1997a. Chemical characteristics and trophic evolution of the deep subalpine Lake Garda (Northern Italy). Mem. Ist. ital. Idrobiol., 56: 51-76.

Salmaso, N., F. Decet, M. Manfrin \& P. Cordella. 1997b. Ricerche limnologiche sul Lago di Garda (1991-1996). Documenta Ist. ital. Idrobiol., 61: 173-199.

Stella, E. 1984. Calanoidi. Guide per il riconoscimento delle specie animali delle acque interne italiane, 14. CNR AQ/1/140: 67 pp.

Stich, H.B. \& W. Lampert. 1981. Predator evasion as an explanation of diurnal vertical migration by zooplankton. Nature, 293: 396-398. 